\title{
Pineapple (Ananas comusus) Plant Material as Supplement for Maize Residue-based Oyster Mushroom Substrate and Reduction of Cadmium Soil Contamination
}

\author{
Igenicious N. Hlerema and Bahlebi K. Eiasu' ${ }^{1}$ \\ Department of Agronomy, University of Fort Hare, Private Bag X1314, Alice \\ 5700, South Africa \\ Susan H. Koch \\ Agricultural Research Council, Plant Protection Research Institute, Private \\ Bag X134, Pretoria 0001, South Africa
}

Additional index words. biological efficiency, biosorption, cadmium, heavy metal pollution, mushroom, pineapple, Pleurotus ostreatus, substrate

\begin{abstract}
Pineapple (Ananas comusus) production generates hard currency and, as a labor-intensive industry, it creates jobs. The profitability of pineapple farming in South Africa faces several challenges, including low yield potential and cadmium (Cd) contamination of soils, which damaged the reputation of the industry. To increase the income of pineapple farmers, research was conducted to evaluate the utilization of pineapple crop residue for oyster mushroom (Pleurotus ostreatus) production and to establish the Cd levels in the mushrooms produced on $\mathrm{Cd}$-contaminated pineapple crop residue. Treatments were maize residue $(M)$, pineapple residue $(P)$, and a mixture of maize and pineapple residues [at 1:1 ratio (on a dry weight basis), $M+P$ ]. Biological efficiencies of $90 \%, 77.6 \%$, and $29 \%$ were recorded for the $M+P, P$, and $M$ treatments, respectively. The $\mathbf{P}$ and $\mathbf{M}+\mathbf{P}$ substrates significantly increased mushroom yield. Mushroom protein contents were $23.3 \%, 18.86 \%$, and $18.81 \%$ (on a dry weight basis) in the $M+P, P$, and $M$ treatments, respectively. Mushrooms in the $\mathbf{P}$ substrate had the highest Cd level $(3.3 \mathrm{mg} / \mathrm{kg})$. In the $M+P$ substrate, $C d$ reduced to a safe level $(0.15 \mathrm{mg} / \mathrm{kg})$. This indicates that mushrooms have biosorption capacity, and could be used to solve the problem of $\mathrm{Cd}$ pollution and increase the income of pineapple production.
\end{abstract}

Oyster mushroom (Pleurotus sp.) is one of the many edible mushroom species that is cultivated for its good flavor and nutritional value (Breene, 1990). Mushroom dry matter contains $30 \%$ to $40 \%$ protein, surpassing the protein content of many other foods (Chang, 2011). Oyster mushrooms can use a large number of plant wastes as substrate (Buah et al., 2010; Madan et al., 1987; Stamets, 2000; Yildiz et al., 1997). Based on previous research, Pleurotus sp. may be capable of using over 200 different types of substrates (Poppe, 2004). The production of edible mushrooms using crop residue as substrate is, therefore, a value-adding process as it converts materials, which are otherwise regarded as wastes, into human food (Stamets, 2000; Zhang et al., 2002). According to Madan et al. (1987), cultivation of edible mushrooms is among the

Received for publication 26 Apr. 2016. Accepted for publication 1 Sept. 2016.

We are grateful to the Gauteng Department of Agriculture and Rural Development for funding this project, Govan Mbeki Research Foundation for the study bursary, and the ARC for the use of their Roodeplaat facilities to conduct the experiments. ${ }^{1}$ Corresponding author. E-mail: beiasu@ufh.ac.za. most efficient ways of recycling agricultural wastes. Buah et al. (2010) also highlighted that cultivation of oyster mushroom is a profitable agribusiness.

Cultivation of oyster mushroom on various lignocellulosic plant materials has been investigated by a number of researchers (Buah et al., 2010; Fanadzo et al., 2010; Madan et al., 1987; Nageswaran et al., 2003; Zhang et al., 2002). Zhang et al. (2002) showed that Pleurotus sp. has a very high saprophytic colonizing ability and can degrade ground rice and wheat straw efficiently. Madan et al. (1987) studied the cultivation of Pleurotus sp. on different wastes, including paddy straw, mulberry stem, and caster stem and leaves. The highest biological efficiency was obtained with paddy straw (108\%) followed by paddy straw supplemented with mulberry stem $(105.4 \%)$. The protein content of the mushrooms varied between $28 \%$ and $34 \%$ of total dry weight.

Pineapple production remains a viable business in South Africa, mainly in the semiarid coastal regions of the Eastern Cape Province. It generates foreign currency and, as a labor-intensive farming business, creates a number of jobs (DAFF, 2011). The profit margin of the industry is small because of low fruit quality and yield potential under the suboptimum climatic conditions (subtropical climate of the area) (DAFF, 2011). In addition, the industry in the Eastern Cape is facing several challenges, including the unwitting contamination of soils and fruits with the heavy metal cadmium (Cd) (DAFF, 2011; Hill and Fraser, 2011). A zinc sulfate fertilizer that was imported from China in 2004 resulted in a $\mathrm{Cd}$ concentration higher than permissible levels in pineapple fruit grown on an area of $\approx 2000$ ha. This has damaged the reputation of the South African fruit industry (DAFF, 2011; Hill and Fraser, 2011). Heavy metal accumulation in soils is often a concern in agricultural production due to the adverse effects on food quality (safety and marketability) and crop growth due to phytotoxicity (Ma et al., 1994).

At the end of the cropping cycles, pineapple crop residue is abundant in the production region. In the past, this crop residue was burned in the pineapple fields. Nowadays it is incorporated into the soil as desirable soil conservation and amendment practices (Ho-a-Shu, 1999). Pineapple plants store more of the $\mathrm{Cd}$ uptake in their vegetative part (DAFF, 2011). Thus, farmers in the Eastern Cape take the entire pineapple crop residue out of their farm to avoid risks of reincorporating plant materials loaded with $\mathrm{Cd}$.

The pineapple crop residue is rich in organic compounds, such as cellulose that could be used as substrate for cultivation of oyster mushrooms (Stamets, 2000). In addition, there is a plan under the theme "bio-efficient pineapple production" aimed at maximizing the income generated from pineapple production by using the different parts of the crop (including the crop residue) for different purposes (D. Murray, personal communication).

Therefore, the aim of the current trials was to evaluate the suitability of using pineapple crop residue for oyster mushroom production as sole or as a supplement to maize plant material and to establish the levels of $\mathrm{Cd}$ in the oyster mushrooms produced on $\mathrm{Cd}$-contaminated pineapple crop residue.

\section{Materials and Methods}

Experimental site description. The experiments were conducted at the Plant Protection Research Institute of the Agricultural Research Council (ARC), Roodeplaat, Pretoria, twice (from 2 Mar. to 30 Apr. 2011 and from 7 Mar. to 10 May 2012, a duration of 2 months $)$. A wooden cabin $(4 \times 6 \mathrm{~m})$ was used as the incubation room during the entire period of the experiments. The wooden cabin (room) was situated in the shade of trees to avoid extreme temperatures. The inner walls of the room were covered with an aluminum cushion to minimize temperature and relative humidity fluctuations, and to protect the wooden structure from rotting. In addition, the floor of the growing room was flooded with water every morning to keep relative humidity as high as possible and 
avoid extremely high temperatures. A layer of river sand $(\approx 3 \mathrm{~cm}$ thick) was put on a dense black plastic sheeting, covering the floor of the room to prevent water runoff during irrigation.

The room has two windows on the eastern (6 m) side (wooden wall) and a wooden door and a window on the western side. Inside the room, there were shelves made up of timber logs on all of the four sides of the room, with one layer on the bottom and another on top. There was a similar shelf in the middle of the room, though it was not used for the experiment.

Treatments. In the current research, maize crop residue alone $(\mathrm{M})$, pineapple crop residue alone $(\mathrm{P})$, and maize and pineapple crop residues mixed at a 1:1 ratio on a dry weight basis $(\mathrm{M}+\mathrm{P})$ were applied as treatments.

Substrate preparation. Maize crop residue (collected from the Research Farm of the ARC) and pineapple plant materials, obtained from Bathurst in the Eastern Cape Province, were milled with the aid of a hammer mill into $2-$ to $3-\mathrm{cm}$ pieces. Thereafter, all substrates were separately sterilized using steam sterilization. For pasteurization, the water was first boiled in a Volcan pot at $120{ }^{\circ} \mathrm{C}$, and then substrates (in permeable bags) were put on top of the boiling water for $2 \mathrm{~h}$ with the lid tightly closed. The sterilized bags of substrates were taken out of the pot, weighed, and placed on a clean table to cool down. The volume of substrate in each bag was $5 \mathrm{~L}$. The weight of the sterilized substrate was used to calculate the initial moisture content of the substrates.

Mushroom inoculation process. The $P$. ostreatus spawn strain HK35, obtained from the Exotic Spawn CC, Pretoria, was used as mushroom inoculum. The substrates were inoculated at a rate of $5 \%$ spawn on substrate wet mass basis, as recommended by Shah et al. (2004) and filled in polythene bags as units of the experiments.

During the spawning period until the substrates were fully colonized by mycelia, the substrate moisture content was maintained at $65 \%$ to $75 \%$, by spraying municipal water into the bags once (0900 HR) or twice (0900 HR and $1400 \mathrm{HR}$ ) a day, depending on the temperature. This insured that the moisture in the growing media was as high as possible. After spawning, 12 evenly distributed holes, of $1-$ to $1.5-\mathrm{cm}$ diameter, were punched into the bags using a sterile razor blade. This allowed fresh air into the bags and pinhead formation.

Harvesting method. The trial was monitored each day, and clusters of mushroom were detached from the substrate by hand when the in-rolled margins of the fruit body began to flatten. For hygiene purposes, latex gloves were worn. Face masks were used to avoid the incident of spore inhalation that could cause respiration difficulties and allergies (Pakela, 1997).

Data recorded. Immediately after harvesting, the fresh weight was determined and the diameter of the caps and the lengths of the stems were measured. Then the mushroom samples were oven-dried at $70{ }^{\circ} \mathrm{C}$ for 1 week to determine dry matter content $(\%)$ and total dry weight produced per bag. Biological efficiency, defined as the percentage conversion of dry substrate into fruit bodies of mushroom, was calculated using Eq. [1], as outlined by Stamets (2000).

$$
\mathrm{BE}(\%)=\frac{\text { Mushoom fresh weight }}{\text { Substrate dry weight }} \times 100
$$

For protein content determination, dry mushroom samples from each bag were taken. Pooled subsamples (per treatment) of $P$. ostreatus fruiting bodies grown in the $\mathrm{M}, \mathrm{M}+\mathrm{P}$, and $\mathrm{P}$ treatments, and spent substrate of the contaminated substrates $(\mathrm{P}$ and $\mathrm{M}+\mathrm{P})$ were ovendried and ground for analysis of $\mathrm{Cd}$ level. The $\mathrm{Cd}$ and protein content analyses were done at the laboratories of the ARC-Animal Production Institute. The $\mathrm{Cd}$ was determined by inductively coupled plasma-mass spectrometry (ICP-MS), using Cd-111 (12.8\% natural abundance) isotope. An internal standard (Indium, In) was used to increase the accuracy (added by diluting the digest solution with indium nitrate to $10 \mathrm{ppb}$ indium). The procedure was based on the standard operating conditions recommended in the instrument manual (Thermo $\mathrm{X}$ Series II). No-acid-containing $\mathrm{Cl}$ was used for digestion to avoid possible interference of $\mathrm{Cl}$ with the ICP-MS determination of certain elements, i.e., only digested nitric acid solutions were used for duplicate analysis and the means of the duplicate values were used (Javaid et al., 2011).

Experimental layout and data analysis. The experiment was laid out as a completely randomized design with four replicates per treatment. Where applicable, the recorded data were subjected to analysis of variance using GenStat for Windows, Release 12.1 (GenStat, 2009). Treatment means were compared using the least significant difference test at $0.05 P$ level.

\section{Results and Discussion}

Spawn run and primordial emergence. In both experiments, the oyster mushroom mycelia colonization rate showed similar trends. On Day 2 after inoculation, whitish colonies started to form in the bags that were filled with sole pineapple and maize-pineapple mix substrates. Accordingly, these two treatments were fully colonized by mycelium by Day 20 . The sole maize substrate treatment was fully colonized only on Day 34.

Spawn run, which is the colonization of substrate phase, is a very important stage in mushroom cultivation (Buah et al., 2010). A low spawn (mycelial colonization) rate can result in a slow spawn run (Royse et al., 2004). High spawn rates could provide more inoculum points, which would provide faster substrate colonization. The slow rate of mycelium growth on the sole maize substrate could be attributed to substrate moisture content. Stamets (2000) recommended that substrate moisture content should be between $60 \%$ and $75 \%$. Thus, the moisture content of the sole maize substrate (Fig. 1) was within the range, but at the lower boundary of the moisture required for optimum mycelium colonization.

Temperature and relative humidity also play an important role during the growth period of the oyster mushrooms. Stamets (2000) reported that the growth rate of $P$. ostreatus accelerated when incubated under temperatures between 15 and $20{ }^{\circ} \mathrm{C}$. In addition, Stamets (1993) recommended different relative humidity levels for different developmental stages for oyster mushrooms, $90 \%$ to $100 \%$ for spawn running, $85 \%$ to $95 \%$ for primordial formation, and $95 \%$ to $100 \%$ for fruit body development. The temperatures for both experiments (from 2 Mar. 2011 to 30 Apr. 2011 and from 7 Mar. to 10 May 2012) are given in Fig. 2. In both experiments, the bag temperatures were relatively stable and most of the time they showed a tendency to be lower in the bags filled with $\mathrm{M}+\mathrm{P}$ substrate.

Primordial emergence. Primordial initiation, the second stage of mycelia growth in the cultivation of mushroom, is dependent on the type of substrate used (Vetayasuporn, 2007). The spawn run on the mixture of maize and pineapple substrate lasted for $20 \mathrm{~d}$ and the primordia emerged on Day 23 after inoculation. These results are in agreement with those of Ahmad (1986), who stated that $P$. ostreatus completed spawn run in 17 to $20 \mathrm{~d}$ on different substrates and time to pinhead formation was noted to be 23 to 27 d. Similarly, Shah et al. (2004) observed that spawn run may take up to 2 to 3 weeks. The spawn run duration difference in the current research could be associated with the variation in substrate moisture contents, $\mathrm{pH}$, and nutrient content at spawning for both the trials conducted in 2011 and 2012, respectively.

Mushroom yield and biological efficiency. The maize-alone substrate $(\mathrm{M})$ resulted in poor mycelium development and significantly lower mushroom yields in both years (Table 1). The $\mathrm{M}+\mathrm{P}$ treatment gave the highest mushroom yield, followed by the pineapple-alone $(\mathrm{P})$ substrate. The maize only substrate $(\mathrm{M})$ yielded the least number

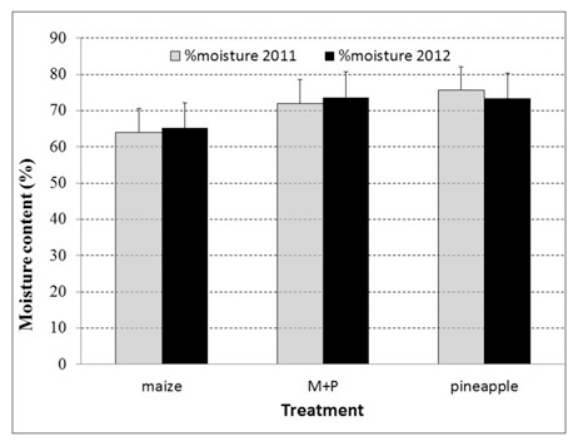

Fig. 1. Substrate moisture content: maize crop residue $(\mathrm{M})$, pineapple-maize mix (1:1 ratio) $(\mathrm{M}+\mathrm{P})$, and pineapple crop residue $(\mathrm{P})$ in 2011 (Season 1) and in 2012 (Season 2). The vertical bars represent least significant difference at $\alpha=5 \%$. 
of mushrooms which is consistent with the poor colonization rate observed in the same substrate during the spawn run time. This was the case for both years (2011 and 2012).

In agreement with these results, Obodai et al. (2003) compared the growth and yield of $P$. ostreatus mushroom on different lignocellulosic by-products, and reported that mushroom yield was directly related to the mycelium growth in the substrate. Due to varying nutrients in the substrates, different mushroom yields have been recorded by various workers. Fanadzo et al. (2010) reported a $97 \%$ biological efficiency after cultivating $P$. ostreatus on maize straw. Chukwurah et al. (2012), on the other hand, reported a $20 \%$ biological efficiency after cultivating oyster mushroom on maize straw. The superiority of the mixture of maize and pineapple substrate was also evidenced in biological efficiency $(90 \%)$, followed by pineapple alone $(78 \%)$. The biological efficiency in the maize alone substrate was as low as 29\% (Fig. 3).

Different ranges of biological efficiencies have been reported from the use of different substrates for oyster mushroom cultivation. When P. ostreatus was grown on sawdust, a biological efficiency of $64.69 \%$ was obtained (Shah et al., 2004). Masenda (2004), on the other hand, reported a biological efficiency of $200 \%$ for the same species grown on groundnut shells supplemented with cotton-seed hulls. In addition, reports indicate that the use of supplements in oyster mushroom cultivation significantly increases yield (Fanadzo et al., 2010; Masenda, 2004; Mwita et al., 2011).

The higher yield in the pineapplesupplemented maize substrate could be attributed to an improvement in the structure and nutritional content of the substrate, making it suitable for mycelia growth, and subsequently increasing the mushroom yield. These results are consistent with that of Nageswaran et al. (2003), who reported an increase in biological efficiency after supplementing paddy straw with water hyacinth.

All the mushrooms had a light and velvetlike texture, probably resulting from the relatively high light intensity and humidity in the culturing room (Pakela, 1997). The results showed that caps of fruiting bodies harvested from the pineapple substrate had larger diameter $(8.41 \mathrm{~cm})$ compared with those grown in the maize alone substrate $(5.85 \mathrm{~cm})$, although the difference was not statistically significant. Stem length showed the same pattern as that of cap size (6.11, 6.70 , and $4.94 \mathrm{~cm}$ for the $\mathrm{P}, \mathrm{M}+\mathrm{P}$, and $\mathrm{M}$ treatments, respectively). The size of mushroom is essential for market purpose, where a wide cap as well as a long stem is desirable to consumers (Mwita et al., 2011).

Protein content. Table 2 shows that the fruiting bodies of $P$. ostreatus harvested from the maize substrate had the highest protein content, followed by those harvested from the pineapple and maize-pineapple mixture substrates. Reports indicated that the protein

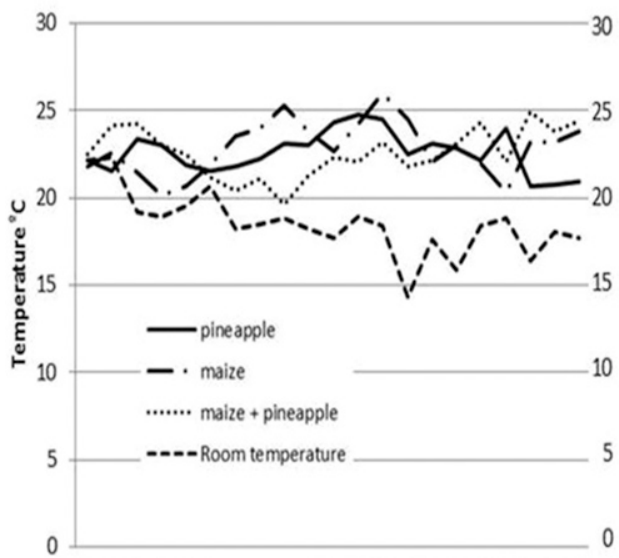

$\begin{array}{cccc}123456789101112131415161718192021 & 123456789101112131415161718192021 \\ \text { (a) } & \text { Days } & \text { (b) } & \text { Days }\end{array}$

Fig. 2. Temperature within the bags and the ambient room temperature (taken midday) for (A) 2011 and (B) 2013 oyster mushroom cultivation durations.

Table 1. The mushroom (Pleurotus ostreatus) fresh and dry yield when grown on maize, pineapple, and maize + pineapple (1:1) substrate.

\begin{tabular}{lcccc}
\hline & \multicolumn{4}{c}{ Mushroom yield parameters } \\
\cline { 2 - 5 } Type of substrate & $\begin{array}{c}\text { Fresh yield } \\
(\mathrm{g} / \mathrm{bag}) 2011\end{array}$ & $\begin{array}{c}\text { Fresh yield } \\
(\mathrm{g} / \mathrm{bag}) 2012\end{array}$ & $\begin{array}{c}\text { Dry wt } \\
(\mathrm{g} / \mathrm{bag}) 2011\end{array}$ & $\begin{array}{c}\text { Dry wt } \\
(\mathrm{g} / \mathrm{bag}) 2012\end{array}$ \\
\hline Maize & $218 \mathrm{c}^{\mathrm{z}}$ & $220 \mathrm{c}$ & $38 \mathrm{c}$ & $24 \mathrm{c}$ \\
$\mathrm{M}+\mathrm{P}$ & $675 \mathrm{a}$ & $655 \mathrm{a}$ & $81 \mathrm{a}$ & $80 \mathrm{a}$ \\
Pineapple & $582 \mathrm{~b}$ & $550 \mathrm{~b}$ & $58 \mathrm{~b}$ & $58 \mathrm{~b}$ \\
Mean & 491 & 475 & 59 & 54 \\
CV \% & 2 & 11 & 14 & 17 \\
Least significant & 18 & 83 & 13 & 15 \\
$\quad$ difference $(\alpha=0.05)$ & & & &
\end{tabular}

$\mathrm{M}+\mathrm{P}=$ Maize crop residue supplemented with pineapple crop residue.

${ }^{\mathrm{z}}$ Means with the same letters are not significantly different from each other.

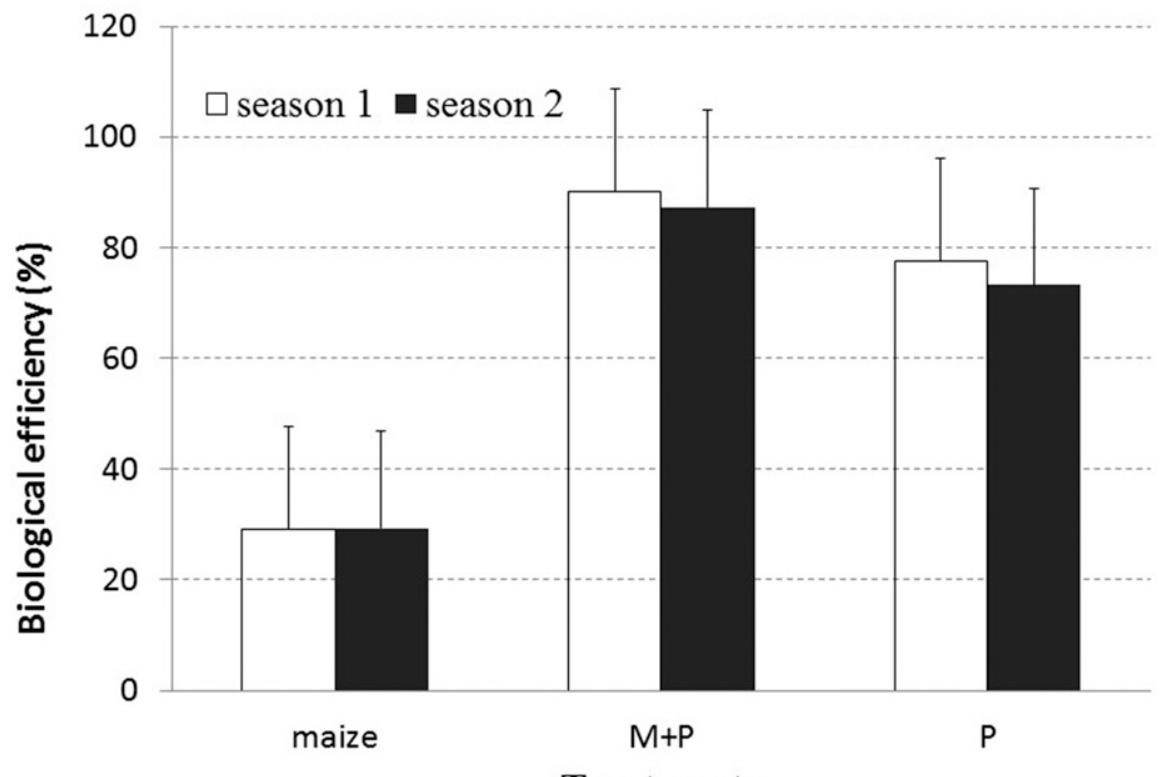

Treatments

Fig. 3. Biological efficiency of Pleurotus ostreatus grown on maize crop residue, pineapple-maize mix (1:1 ratio) $(\mathrm{M}+\mathrm{P})$, and pineapple crop residue $(\mathrm{P})$ in 2011 (Season 1) and in 2012 (Season 2). The vertical bars represent least significant difference at $\alpha=5 \%$.

content of mushroom increases with nitrogen content in the substrates (Sharma and Madan, 1993). Stamets (2000) observed that maize crop residue contains higher nitrogen content
(1.84\%) compared with pineapple vegetative material $(0.64 \%)$, which could be an explanation for the relatively higher protein content in the mushroom grown on the maize 
Table 2. The average protein and cadmium content of the mushroom (Pleurotus ostreatus) fruit bodies from the different substrates for both years.

\begin{tabular}{lcc}
\hline Treatment & $\begin{array}{c}\text { Protein } \\
(\%)\end{array}$ & $\begin{array}{c}\text { Cadmium } \\
(\mathrm{mg} / \mathrm{kg})\end{array}$ \\
\hline Maize & $23.30 \mathrm{a}^{\mathrm{z}}$ & $0.04 \mathrm{~b}$ \\
$\mathrm{M}+\mathrm{P}$ & $18.80 \mathrm{~b}$ & $0.15 \mathrm{~b}$ \\
Pineapple & $18.86 \mathrm{~b}$ & $3.30 \mathrm{a}$ \\
Grand mean & 20.30 & 1.16 \\
$\mathrm{CV} \%$ & 5.40 & 8.00 \\
Least significant & 3.02 & 0.13 \\
$\quad$ difference $(\alpha=0.05)$ & &
\end{tabular}

$\bar{M}+\mathrm{P}=$ Maize crop residue supplemented with pineapple crop residue.

${ }^{\mathrm{z}}$ Means with the same letters are not significantly different from each other.

Table 3. Initial cadmium levels in pineapple (Ananas comusus) vegetative material and the final cadmium level in the spent substrate.

\begin{tabular}{|c|c|}
\hline Substrate & $\begin{array}{c}\text { Cadmium } \\
(\mathrm{mg} / \mathrm{kg})\end{array}$ \\
\hline Sole pineapple crop residue & 8.96 \\
\hline $\begin{array}{l}\text { Sole pineapple spent } \\
\text { substrate pineapple }\end{array}$ & 10.7 \\
\hline $\begin{array}{l}\text { Maize-pineapple mix } \\
\text { spent substrate }\end{array}$ & 5.15 \\
\hline
\end{tabular}

substrate in the current experiments. Higher concentrations of heavy metals in substrates have also been reported to reduce biological efficiency and protein content of mushrooms (Das, 2005).

Cadmium content. Mushrooms are not selective in taking up nutrients from the substrates. They adsorb even heavy metals contained in the substrate materials (Javaid et al., 2011). However, the concentration of elements in the fruiting bodies could be species dependent (Kalač and Svoboda, 2000). In agreement with these reports, the fruiting bodies of $P$. ostreatus harvested from the pineapple substrate had the high level of Cd (3.3 mg/kg dry weight) (Table 3 ), which is more than the maximum tolerable level $(0.2 \mathrm{mg} / \mathrm{kg}$ wet weight) in oyster mushroom, according to European Food Safety Authority (EFSA) and Food and Agriculture Organization (FAO)/World Health Organization (WHO) conventions (Codex Alimentarius, 2001; EFSA, 2009). However, when the pineapple crop residue was used as a supplement to the maize-based substrate, the level of $\mathrm{Cd}$ reduced to levels below the FAO/WHO safety standards.

These results support the report of Dutta et al. (2007), who investigated costeffectiveness and sustainability of mushroom cultivation on substrates contaminated with heavy metals. The authors indicated that supplementing the contaminated plant material with other substrates minimized the level of heavy metals in Pleurotus sajor-caju. Das (2005) also reported that mushrooms can act as an effective biosorbent of toxic metals. Thus, the use of pineapple residue from the Eastern Cape Province as a supplement substrate for oyster mushroom cultivation could have two objectives: 1) using the pineapple plant materials for producing mushroom, which increase the income of the farmers, and 2) reducing the $\mathrm{Cd}$ contamination by taking away the $\mathrm{Cd}$ stored in the crop residue. Since 2006, such practices have reduced the Cd level in plants and fruits in the Eastern Cape (DAFF, 2011). However, the mushrooms produced on sole pineapple crop residue (contaminated with $\mathrm{Cd}$ ) would not be fit for human consumption and also the spent mushroom substrate would contain high levels of heavy metals (Table 3 ).

The current results proved that pineapple crop residue can be used as a supplement for maize-based substrate in the cultivation of $P$. ostreatus. The substrate significantly improved mushroom fresh and dry yields. It also improved biological efficiency in this trial. From these results, it can be concluded that mushroom producers, in pineapple production area, can use pineapple crop residue to supplement the maize substrate to obtain high yield and biological efficiency within a short period of time.

These results also showed that the abundant pineapple crop residue in the Cd-contaminated area of the Eastern Cape Province can be used to produce mushroom which is safe for human consumption. The removal of the crop residue that contains a high level of $\mathrm{Cd}$ from the field for production of mushroom also reduces the Cd level of the affected areas. Moreover, the present study highlights that $P$. ostreatus has a degree of biosorption capacity which could be exploited as cost-effective technology to solve problems of heavy metal pollution.

\section{Literature Cited}

Ahmad, I. 1986. Some studies on oyster mushroom (Pleurotus spp.) on waste material of corn industry. MS Thesis, Univ. of Agriculture, Faisalabad, Pakistan.

Breene, W.M. 1990. Nutritional and medicinal value of specialty mushrooms. J. Food Prot. 53:883-894.

Buah, J.N., G.C. Van Der Puijie, E.A. Bediako, E.A. Abole, and F. Showemimo. 2010. The growth and yield performance of oyster mushroom (Pleurotus ostreatus) on different substrates. Biotechnology 9:338-342.

Chang, S.T. 2011. Training manual on mushroom cultivation technology. 2 Dec. 2011.<http://www. unapcaem.org/publication/TM-mushroom.pdf $>$.

Chukwurah, N.F., S.C. Eze, N.V. Chiejina, C.C. Onyeonagu, K.I. Ugwuoke, F.S.O. Ugwu, C.G. Nkwonta, E.U. Akobueze, C.B. Aruah, and C.U. Onwuelughasi. 2012. Performance of oyster mushroom (Pleurotus ostreatus) in different local agricultural waste materials. Afr. J. Biotechnol. 11:8979-8985.

Codex Alimentarius. 2001. Codex maximum levels for cadmium in cereals, pulses and legumes. Joint FAO/WHO standards, CAC/GL 39-2001.

Department of Agriculture, Forestry and Fishery (DAFF). 2011. A profile of the South African pineapple market value. 2 Jan. 2015. <http:// www.daff.gov.za/docs/amcp/pineapplemvcp201112.pdf $>$.

Das, N. 2005. Heavy metals biosorption by mushrooms. Nat. Prod. Radiance 4:454-459.

Dutta, S., R.N. Medda, and N.C. Chatterjee. 2007. Cost-effective sustainability of mushroom cultivation and the associated heavy metal contamination. J. Mycopathol. Res. 45: $45-50$.

European Food Safety Authority (EFSA). 2009. Cadmium in food. Scientific opinion of the panel on contaminants in the food chain. EFSA J. 980:1-139.

Fanadzo, M., D.T. Zireva, E. Dube, and A.B. Mashingaidze. 2010. Evaluation of various substrate and supplements for biological efficiency of Pleurotus sajor-caju and Pleurotus ostreatus. Afr. J. Biotechnol. 9:27562761.

GenStat. 2009. GenStat Release 12.1 for PC/ Windows Vista, VSN International Ltd, Hemel Hempstead, UK.

Hill, G. and G. Fraser. 2011. The impact of contaminated fertilizer on pineapple growers in the Eastern Cape, South Africa. 6 Dec. 2011. $<$ http://rhodes-za.academia.edu $>$.

Ho-a-Shu, V. 1999. Pineapple production practices. Department of Horticulture National Agricultural Research Institute, Monday Repos, East Coast Demerara.

Javaid, A., R. Bajwa, U. Shafique, and J. Anwar. 2011. Removal of heavy metals by adsorption on Pleurotus ostreatus. Biom. and Bioen. 35:1675-1682.

Ma, Q.Y., S.J. Traina, and T.J. Logan. 1994. Effect of aqueous $\mathrm{Al}, \mathrm{Cd}, \mathrm{Fe}$ (II), Ni and $\mathrm{Zn}$ on $\mathrm{Pb}$ immobilization by hydroxyapatite. Environ. Sci. Technol. 28:1219-1228.

Kalač, P. and L. Svoboda. 2000. A review of trace element concentration in edible mushrooms. Food Chem. 69:273-281.

Madan, M., P. Vasudevan, and S. Sharma. 1987. Cultivation of Pleurotus sajor-caju on different wastes. Biol. Wastes 22:241-250.

Masenda, E. 2004. Groundnut shells, p. 120-122. In: Mushroom Growers' Handbook 1: Oyster Mushroom Cultivation. MushWorld-HEINEART Inc., Seoul, Republic of Korea.

Mwita, L.N., S.L. Lyantagaye, and A.M. Mshandete. 2011. The effect of the interaction of varying chicken manure supplement levels with three different solid sisal waste substrate on sporocarp cap lengths and diameters, stipe lengths and diameters and dry weights of Coprinus cinereus (Schaeff) S. Gray s.lat. Afr. J. Biotechnol. 10:1172-1180.

Nageswaran, M., A. Gopalakrishnan, M. Ganesan, A. Vedhamurthy, and E. Selvaganapathy. 2003. Evaluation of waterhyacinth and paddy straw waste for culture of oyster mushrooms. J. Aquat. Plant Mgt. 41:122-123.

Obodai, M., J. Cleland-Okine, and K.A. Vowotor. 2003. Comparative study on the growth and yield of Pleurotus ostreatus mushroom on different lignocellulosic by-products. J. Ind. Microbiol. Biotechnol. 30:146-149.

Pakela, Y.P. 1997. Development of rural oyster mushroom Pleurotus spp. industry in South Africa. MS thesis, University of Pretoria, Pretoria, South Africa.

Poppe, J. 2004. Agricultural waste as substrate for oyster mushroom, p. 75-85. In: Mushroom Growers' Handbook 1: Oyster Mushroom Cultivation. MushWorld-HEINEART Inc., Seoul, Republic of Korea.

Royse, D.J., T.W. Rhodes, S. Ohga, and J.E. Senchez. 2004. Yield, mushroom size and time of production of Pleurotus cornucopiae (oyster mushroom) grown on switch grass substrate spawned and supplemented at various rates. Bioresour. Technol. 91:85-91.

Shah, Z.A., M. Ashraf, and M. Ishtiaq. 2004. Comparative study on cultivation and yield performance of oyster mushroom Pleurotus 
ostreatus on different substrates. Pak. J. Nutr. 3:158-160.

Sharma, S. and M. Madan. 1993. Microbial protein from leguminous and non-leguminous substrates. Acta Biotechnol. 13:131-139.

Stamets, P. 1993. Growing gourmet and medicinal mushrooms. Ten Speed Press, Olympia, WA.
Stamets, P. 2000. Growing gourmet and medicinal mushrooms. Ten Speed Press, Berkeley, CA.

Vetayasuporn, S. 2007. Using cattails (Typha latifolia) as a substrate for Pleurotus ostreatus (Fr.) Kummer cultivation. J. Biol. Sci. 7:218-221.

Yildiz, A., M. Karakaplan, and F. Aydin. 1997. Studies on Pleurotus ostreatus (Jacq.ex Fr.)
Kum. var. salignus (Pers. ex Fr.) Konr. Et Maubl.: Cultivation, proximate composition, organic and mineral composition of carpophores. Food Chem. 61:127-130.

Zhang, R., L.I. Xiujin, and J.G. Fadel. 2002. Oyster mushroom cultivation with rice and wheat straw. Bioresour. Technol. 82:277-284. 